\title{
HERBAGE YIELDS AND QUALITY TRAITS OF DIFFERENT SAINFOIN GENOTYPES
}

\author{
Isa Tepe ${ }^{1}$, Mahmut Kaplan ${ }^{1, *}$ \\ ${ }^{1}$ Erciyes University, Faculty of Agriculture, Department of Field Crops, Kayseri, Turkey
}

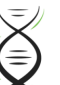

Current Trends in

Natural Sciences

\begin{abstract}
This study was conducted to determine green herbage yield, dry herbage yield, crude protein yield, ADF, NDF ratios, crude protein ratio, crude oil, crude ash and tannin ratios of 26 sainfoin genotypes and to identify superior genotypes in terms of yield and quality traits. Experiments were conducted in randomized blocks design with tree replications in 2017-2018 growing season. Significant differences were observed in investigated traits of the genotypes. Green herbage yields varied between 765.36 - $2737.25 \mathrm{~kg} / \mathrm{da}$, dry herbage yields between 281.01 - $693.42 \mathrm{~kg} / \mathrm{da}$, crude protein yields between 48.96 - $133.34 \mathrm{~kg} / \mathrm{da}$, crude protein ratios between 11.81 - 23.78\%, crude ash ratios between $4.42-8.02 \%$, ADF ratios between $37.12-56.76 \%$, NDF ratios between $42.12-67.01 \%$, crude oil ratios between $0.81-1.73 \%$ and condensed tannin contents 1.35 - 5.78\%. Therefore, it was recommended for Kayseri province and the regions with similar climate and soil conditions.
\end{abstract}

Keywords: chemical composition, herbage yield, sainfoin.

\section{INTRODUCTION}

Ever-increasing stress exerted by global warming and resultant droughts on agricultural practices clearly revealed the significance of feed crops in unirrigated lands. Feed crops have various positive impacts on soil physical and chemical characteristics, yield and quality of subsequent crops. They also provide significant source of roughage and feed in livestock industry (Aksay et al., 2005; Yolcu and Tan, 2008).

Sainfoin (Onobrychis viciifolia Scop.) belongs to legumes (Fabaceae) family. It is a perennial feed crop with high quality roughage able to be grown under different ecological conditions (Elci, 2005). Sainfoin is highly resistant to low temperatures and droughts, thus could successfully be grown in barren lands. It is rich in protein, minerals and vitamins (Avci et al., 2014). Sainfoin cultivars exhibit a great variation in yield and quality traits. Therefore, it is quite significant that genotypes and cultivars should be experimented for yield and quality traits under different climate and soil conditions (Harmanlioglu, 2019). Animal feeding behaviors, feed consumptions, digestibility and conversion into animal products are directly related to feed quality. Feed quality is determined through measurements for physical, chemical and biological traits of the feeds (Ulger and Kaplan, 2016). Previous studies mostly focused on chemical composition, metabolic energy and digestibility of different sainfoin cultivars, but the number of studies investigating yield and quality traits of sainfoin genotypes is quite limited. 
This study was conducted to determine green and dry herbage yield, crude protein yield, ADF, NDF, crude protein, crude oil, crude ash and tannin ratios of 26 sainfoin genotypes and to identify superior genotypes in terms of yield and quality traits.

\section{MATERIALS AND METHODS}

In this study, 26 sainfoin genotypes supplied from Field Crops Department of Erciyes University Agricultural faculty were used as the plant material of the experiments. Experiments were conducted in randomized blocks design with 3 replications over the experimental fields of Agricultural Research Center of Erciyes University. Seeds were sown in April 2017. Measurements were not able to be performed in the first year of the experiments. Experimental plots were $5.0 \times 3.0$ $\mathrm{m}$. Row spacing was $50 \mathrm{~cm}$. Fertilization was practiced at sowing as to have $3 \mathrm{~kg} / \mathrm{da} \mathrm{N}$ and $6 \mathrm{~kg} / \mathrm{da}$ $\mathrm{P}_{2} \mathrm{O}_{5}$. Throughout the growing season, manual weeding was practiced for weed control. Plants were grown without irrigation. Harvest was practiced at 50\% flowering stage. At harvest, side rows and $0.5 \mathrm{~m}$ sections from the top and bottom of the plots were omitted as to consider side effects and harvested plants were weighed to get green herbage yields. Plant samples were dried at $70{ }^{\circ} \mathrm{C}$ until a constant mass and weighed to get dry herbage yields.

Kayseri province has a temperate climate with hot and dry summers and cold and snowy winters. Monthly total precipitations were lower than the long-term averages in 2017 and greater in 2018. Monthly average temperatures were similar with the long-term averages in both years. Experimental soils were loamy in texture, slightly alkaline and unsaline. Soils were insufficient in available phosphorus, moderate in organic matter, high in available potassium and low in lime.

Dry samples were ground to pass through $1 \mathrm{~mm}$ sieve. For crude ash content, samples were dried in an ash oven at $550^{\circ} \mathrm{C}$ for 8 hours. Ether extraction method was used to determine crude oil contents with the use of a Soxhlet collector device. Sample nitrogen $(\mathrm{N})$ contents were determined with Kjeldahl method and crude protein contents were determined with the use of $\mathrm{Nx} 0.6$ formula (AOAC, 1990). NDF analysis was conducted with the use of Van Soest and Wine (1967) and ADF analysis with Van Soest (1963) methods. Condensed tannin contents were determined with the use of Buthanol-HCl method (Makkar et al., 1995).

Experimental data on herbage yields and quality traits of different sainfoin genotypes were subjected to analysis of variance with the use of SAS (Statistical Analysis Software) software. Significant means were compared with the use of LSD test (SAS Institute, 1999).

\section{RESULTS AND DISCUSSIONS}

The lowest green herbage yield $(683.46 \mathrm{~kg} / \mathrm{da})$ was obtained from EUOS9 genotype and the greatest green herbage yield $(2737.25 \mathrm{~kg} / \mathrm{da})$ was obtained from EUOS1 genotype. The average green herbage yield of sainfoin genotypes was calculated as $1328.39 \mathrm{~kg} / \mathrm{da}$. The lowest dry herbage yield $(281.01 \mathrm{~kg} / \mathrm{da})$ was obtained from EUOS2 genotype and the greatest dry herbage yield $(693.42 \mathrm{~kg} / \mathrm{da})$ was obtained from EUOS1 genotype. The average dry herbage yield of the sainfoin genotypes was calculated as $405.48 \mathrm{~kg} / \mathrm{da}$. The lowest crude protein yield (48.96 kg/da) was obtained from EUOS2 genotype and the greatest crude protein yield $(133.34 \mathrm{~kg} / \mathrm{da})$ was obtained from EUOS 1 genotype. The average crude protein yield of the sainfoin genotypes was calculated as $76.53 \mathrm{~kg} / \mathrm{da}$. 
Current Trends in Natural Sciences

Vol. 9, Issue 17, pp. 83-88, 2020

https://doi.org/10.47068/ctns.2020.v9i17.009

Current Trends in Natural Sciences (on-line)

ISSN: 2284-953X

ISSN-L: 2284-9521
Current Trends in Natural Sciences (CD-Rom)

ISSN: 2284-9521

ISSN-L: 2284-9521

Table 1. Green and dry herbage and crude protein yields of sainfoin genotypes

\begin{tabular}{|c|c|c|c|}
\hline Genotypes & $\begin{array}{c}\text { Green Herbage Yield } \\
(\mathrm{kg} / \mathrm{da})\end{array}$ & $\begin{array}{c}\text { Dry Herbage Yield } \\
(\mathrm{kg} / \mathrm{da})\end{array}$ & $\begin{array}{c}\text { Crude Protein Yield } \\
(\mathrm{kg} / \mathrm{da})\end{array}$ \\
\hline EUOS1 & $2737.25 \mathrm{a}$ & $693.42 \mathrm{a}$ & $133.34 \mathrm{a}$ \\
\hline EUOS2 & $843.12 \mathrm{qp}$ & $281.01 \mathrm{~m}$ & $48.96 \mathrm{~m}$ \\
\hline EUOS3 & $1546.46 \mathrm{~h}$ & $556.55 \mathrm{c}$ & $77.81 \mathrm{gh}$ \\
\hline EUOS4 & 1829.45 ef & $549.00 \mathrm{c}$ & $107.50 \mathrm{~cd}$ \\
\hline EUOS5 & $964.10 \mathrm{mn}$ & $322.56 \mathrm{j}$ & $49.78 \mathrm{~lm}$ \\
\hline EUOS6 & $1465.97 \mathrm{i}$ & $502.11 \mathrm{e}$ & 88.88 ef \\
\hline EUOS7 & $1005.09 \mathrm{~lm}$ & $320.07 \mathrm{j}$ & $61.06 \mathrm{ijkl}$ \\
\hline EUOS8 & $765.36 \mathrm{r}$ & $314.34 \mathrm{jk}$ & $55.76 \mathrm{jklm}$ \\
\hline EUOS9 & $683.46 \mathrm{~s}$ & $292.62 \mathrm{~lm}$ & $56.25 \mathrm{ijklm}$ \\
\hline EUOS10 & $1740.67 \mathrm{~g}$ & $399.07 \mathrm{~g}$ & $82.43 \mathrm{fg}$ \\
\hline EUOS11 & 892.46 nop & $295.70 \mathrm{klm}$ & $49.93 \mathrm{~lm}$ \\
\hline EUOS12 & $2222.86 \mathrm{~b}$ & $547.17 \mathrm{c}$ & $100.15 \mathrm{de}$ \\
\hline EUOS13 & $941.91 \mathrm{mn}$ & $346.13 \mathrm{i}$ & $75.11 \mathrm{gh}$ \\
\hline EUOS14 & 895.71 nop & $298.33 \mathrm{klm}$ & $62.00 \mathrm{ijk}$ \\
\hline EUOS15 & $1775.64 \mathrm{fg}$ & $498.04 \mathrm{e}$ & $118.46 \mathrm{bc}$ \\
\hline EUOS16 & $962.24 \mathrm{mn}$ & $314.39 \mathrm{jk}$ & $53.02 \mathrm{klm}$ \\
\hline EUOS17 & 1046.521 & $344.71 \mathrm{i}$ & $76.67 \mathrm{gh}$ \\
\hline EUOS18 & 920.64 no & $348.06 \mathrm{i}$ & 67.44 hij \\
\hline EUOS19 & $780.89 \mathrm{qr}$ & $303.59 \mathrm{jkl}$ & $52.51 \mathrm{klm}$ \\
\hline EUOS20 & $1215.27 \mathrm{j}$ & $369.38 \mathrm{~h}$ & $80.05 \mathrm{fg}$ \\
\hline EUOS21 & $1130.40 \mathrm{k}$ & $347.12 \mathrm{i}$ & 66.90 hij \\
\hline EUOS22 & 857.61 op & $314.07 \mathrm{jk}$ & $67.70 \mathrm{hi}$ \\
\hline EUOS23 & $1245.75 \mathrm{j}$ & $384.75 \mathrm{gh}$ & $74.47 \mathrm{gh}$ \\
\hline EUOS24 & $2145.94 \mathrm{c}$ & $526.82 \mathrm{~d}$ & $62.11 \mathrm{ijk}$ \\
\hline EUOS25 & $2060.94 \mathrm{~d}$ & $598.51 \mathrm{~b}$ & $123.43 \mathrm{ab}$ \\
\hline EUOS26 & $1862.41 \mathrm{e}$ & $475.08 \mathrm{f}$ & $98.00 \mathrm{de}$ \\
\hline Means & 1328.39 & 405.48 & 76.53 \\
\hline LSD & 76.36 & 19.12 & 11.79 \\
\hline
\end{tabular}

The lowest crude protein ratio (11.81\%) was obtained from EUOS24 genotype and the greatest crude protein ratio $(23.78 \%)$ was obtained from EUOS15 genotype. The average crude protein ratio of the sainfoin genotypes was calculated as $18.93 \%$. The lowest crude ash content $(4.45 \%)$ was obtained from EUOS12 genotype and the greatest crude ash content (8.02\%) was obtained from EUOS15 genotype. The average crude ash content of the sainfoin genotypes was calculated as $6.04 \%$. The lowest crude oil content $(0.63 \%)$ was obtained from EUOS17genotype and the greatest crude oil content $(1.73 \%)$ was obtained from EUOS21 genotype. The average crude oil content of the sainfoin genotypes was calculated as $1.13 \%$. ADF ratios of sainfoin genotypes varied between 37.12 - 56.76\% with an average value of $45.67 \%$. The lowest ADF ratio was obtained from EUOS14 genotype and the greatest from EUOS26 genotype. NDF ratios of sainfoin genotypes 
Current Trends in Natural Sciences

Vol. 9, Issue 17, pp. 83-88, 2020

https://doi.org/10.47068/ctns.2020.v9i17.009

Current Trends in Natural Sciences (on-line)

ISSN: 2284-953X

ISSN-L: 2284-9521
Current Trends in Natural Sciences (CD-Rom)

ISSN: 2284-9521

ISSN-L: 2284-9521

varied between 42.12 - $67.01 \%$ with an average value of $53.95 \%$. The lowest NDF ratio was obtained from EUOS14 genotype and the greatest from EUOS3 genotype. Condensed tannin contents of sainfoin genotypes varied between $1.35-5.78 \%$ with an average value of $3.22 \%$. The lowest condensed tannin content was obtained from EUOS3 genotype and the greatest from EUOS19 genotype (Table 2).

Table 2. Biochemical properties of sainfoin genotypes

\begin{tabular}{|c|c|c|c|c|c|c|}
\hline Genotypes & $\begin{array}{c}\text { Crude Protein } \\
(\%)\end{array}$ & $\begin{array}{c}\text { Crude Ash } \\
(\%)\end{array}$ & $\begin{array}{c}\text { Crude Oil } \\
(\%)\end{array}$ & $\operatorname{ADF}(\%)$ & NDF (\%) & $\begin{array}{c}\text { Condense } \\
\text { Tannin (\%) }\end{array}$ \\
\hline EUOS1 & 19.25 bcdef & $5.65 \mathrm{ijkl}$ & $0.88 \mathrm{def}$ & $48.46 \mathrm{bcd}$ & $54.26 \mathrm{def}$ & 3.74 cdefg \\
\hline EUOS2 & $17.43 \mathrm{efg}$ & 5.93 ghij & 1.20 abcde & 44.96 cdefgh & 55.14 cdef & 3.72 cdefg \\
\hline EUOS3 & $14.00 \mathrm{hi}$ & 4.79 op & $0.81 \mathrm{ef}$ & $56.21 \mathrm{a}$ & $67.01 \mathrm{a}$ & $1.35 \mathrm{k}$ \\
\hline EUOS4 & $19.57 \mathrm{bcdef}$ & $5.46 \mathrm{jklmn}$ & 1.27 abcde & 46.28 bcdefg & $52.97 \mathrm{defg}$ & $3.35 \mathrm{fgh}$ \\
\hline EUOS5 & $15.41 \mathrm{gh}$ & $6.25 \mathrm{fgh}$ & $1.51 \mathrm{abc}$ & 44.21 defghi & $53.53 \mathrm{def}$ & 3.56 defgh \\
\hline EUOS6 & $17.71 \mathrm{defg}$ & $5.56 \mathrm{ijklm}$ & $1.57 \mathrm{ab}$ & 46.40 bcdef & $53.18 \mathrm{def}$ & 3.08 fghi \\
\hline EUOS7 & 19.07 bcdef & $5.33 \mathrm{klmn}$ & 1.27 abcde & 47.49 bcde & $57.80 \mathrm{bcd}$ & 4.42 bcde \\
\hline EUOS8 & 17.74 defg & 5.75 hijk & $0.92 \mathrm{def}$ & 42.56 efghij & $51.37 \mathrm{efgh}$ & $5.13 \mathrm{ab}$ \\
\hline EUOS9 & 19.25 bcdef & 5.16 lmno & $1.14 \mathrm{bcdef}$ & $48.09 \mathrm{bcd}$ & $53.13 \mathrm{def}$ & $3.88 \mathrm{cdef}$ \\
\hline EUOS10 & 20.67 abcde & $5.09 \mathrm{mno}$ & 0.99 cdef & $49.63 \mathrm{bc}$ & $58.60 \mathrm{bcd}$ & $1.72 \mathrm{jk}$ \\
\hline EUOS11 & $16.81 \mathrm{fgh}$ & $7.08 \mathrm{~cd}$ & 1.19 abcdef & 46.29 bcdefg & $55.98 \mathrm{cde}$ & $2.19 \mathrm{ijk}$ \\
\hline EUOS12 & 18.30 cdefg & $4.45 \mathrm{p}$ & $0.86 \mathrm{ef}$ & $50.83 \mathrm{~b}$ & $62.65 \mathrm{ab}$ & $1.87 \mathrm{jk}$ \\
\hline EUOS13 & $21.69 \mathrm{ab}$ & $7.01 \mathrm{~cd}$ & 1.08 bcdef & 46.33 bcdef & $56.40 \mathrm{cde}$ & $1.81 \mathrm{jk}$ \\
\hline EUOS14 & $20.78 \mathrm{abcd}$ & 6.92 cde & 1.20 abcde & $37.12 \mathrm{k}$ & $42.12 \mathrm{i}$ & 3.42 efgh \\
\hline EUOS15 & $23.78 \mathrm{a}$ & $8.02 \mathrm{a}$ & $0.89 \mathrm{def}$ & 46.56 bcde & $60.73 \mathrm{bc}$ & $2.11 \mathrm{ijk}$ \\
\hline EUOS16 & $16.86 \mathrm{fgh}$ & $6.18 \mathrm{gh}$ & $1.16 \mathrm{bcdef}$ & 44.12 defghi & 55.49 cde & $4.68 \mathrm{bc}$ \\
\hline EUOS17 & $22.25 \mathrm{ab}$ & $7.28 \mathrm{bc}$ & $0.63 \mathrm{f}$ & 41.28 fghijk & $49.56 \mathrm{fgh}$ & $4.52 \mathrm{bcd}$ \\
\hline EUOS18 & 19.39 bcdef & $6.75 \mathrm{def}$ & $0.87 \mathrm{ef}$ & $46.20 \mathrm{bcdefg}$ & $53.88 \mathrm{def}$ & $2.62 \mathrm{hij}$ \\
\hline EUOS19 & $17.26 \mathrm{fgh}$ & 5.33 klmn & 1.33 abcde & 41.11 ghijk & $51.41 \mathrm{efgh}$ & $5.78 \mathrm{a}$ \\
\hline EUOS20 & $21.66 \mathrm{ab}$ & $6.22 \mathrm{gh}$ & 1.30 abcde & 42.60 efgij & $51.78 \mathrm{efgh}$ & 3.40 efgh \\
\hline EUOS21 & 19.36 bcdef & $6.19 \mathrm{gh}$ & $1.73 \mathrm{a}$ & $39.66 \mathrm{ijk}$ & 47.08 ghi & 3.10 fghi \\
\hline EUOS22 & $21.58 \mathrm{abc}$ & $7.69 \mathrm{ab}$ & 1.21 abcde & $38.67 \mathrm{jk}$ & $45.99 \mathrm{hi}$ & 2.74 ghij \\
\hline EUOS23 & $19.35 \mathrm{bcdef}$ & $5.98 \mathrm{ghi}$ & $1.42 \mathrm{abcd}$ & 40.02 hijk & $46.40 \mathrm{hi}$ & $1.98 \mathrm{jk}$ \\
\hline EUOS24 & $11.81 \mathrm{i}$ & $5.00 \mathrm{no}$ & $0.82 \mathrm{ef}$ & $50.98 \mathrm{~b}$ & 57.09 bcde & $1.98 \mathrm{jk}$ \\
\hline EUOS25 & 20.63 abcde & $5.52 \mathrm{ijklm}$ & $1.15 \mathrm{bcdef}$ & 44.64 cdefghi & $55.25 \mathrm{cdef}$ & 3.74 cdefg \\
\hline EUOS26 & 20.63 abcde & $6.43 \mathrm{efg}$ & $1.03 \mathrm{bcdef}$ & $56.76 \mathrm{a}$ & $54.00 \mathrm{def}$ & 3.74 cdefg \\
\hline Means & 18.93 & 6.04 & 1.13 & 45.67 & 53.95 & 3.22 \\
\hline LSD & 3.34 & 0.51 & 0.55 & 5.19 & 5.92 & 1.05 \\
\hline
\end{tabular}

The ADF, NDF, crude protein, crude oil, crude ash and tannin ratios of 16 sainfoin genotypes were investigated in this study and significant differences were observed in herbage yield and quality traits of the genotypes.

It was reported that herbage yields were significantly influenced by plant genetics, sowing dates, climate and soil conditions (Dumlu et al., 2017; Engin and Mut, 2017). Crude protein ratio of the 
feeds and cell membrane components (ADF and NDF) are among the most significant quality criteria (Assefa and Ledin, 2001; Parlak et al., 2014). The differences in dry biomass and protein ratios of the present genotypes were attributed to differences in plant genetics, plant leaf, spike and stem ratios, ripening stages, climate factors and fertilization practice (Ball et al., 2001). Increasing ADF and NDF ratios reduce animal feed consumptions. It was also reported that high ADF and NDF ratios decreased digestible energy. Just because of significant effects on feed digestibility, low ADF and NDF ratios are desired in quality feeds (Van Soest, 1994; Bozkurt, 2011; Canbolat and Karaman 2009). High condensed tannin ratios also reduce digestion of feed proteins, thus have negative impacts on feed digestibility (Kumar and Singh, 1984). However, low condensed tannin ratios $(2-3 \%)$ prevent excessive protein degradation in rumen, thus have positive impacts on feed digestibility (Barry, 1987). Plant oil contents are not constant and vary with the plant genetics, morphology, physiology, ecological conditions and cultural practices (Baydar, 2000). Crude ash is composed of unburnt portion of the dry biomass and is used as an indicator of mineral content of the feed (Gençtan, 1998). Minerals are not synthesized in animal body, so they should be supplied externally. Mineral contents up to 5\% is accepted as complying with the standards, but upper limit of the minerals may vary from feed to feed (Anonymous, 2011).

\section{CONCLUSIONS}

Present findings revealed that EUOS1 genotype was prominent for yield components. Therefore, it is recommended for Kayseri province and the regions with similar climate and soil conditions. Further research is recommended for potential use of this genotype in sainfoin breeding programs.

\section{REFERENCES}

Aksay, C. S., Ketenoğlu, O., Kurt, L., (2005). Global Warming and Climatic Change. Selçuk Üniversitesi Fen Fakültesi Fen Dergisi, 1(25), 29-42.

Anonim. (2011). Tarım ve Köy İşleri Bakanlığı'ndan Resmi Gazete [Official Gazette from the Ministry of Agriculture and Rural Affairs], Retrieved April 18, 2011, from "www.resmigazete.gov.tr/eskiler/2011/12/20111227-121.docx",

AOAC, (1990). Official method of analysis. Association of official analytical chemists 15th.edition, pp.66-88.

Assefa, G., Ledin, I. (2001). Effect of variety, soil type and fertilizer on the establishment, growth, forage yield, quality and voluntary intake by cattle of oats and vetches cultivated in pure stand and mixtures. Animal Feed Sci. Technol., 92, 95-111.

Avci, M.A., Ozkose, A., Tamkoc, A. (2013). Study of Genotype x Environment Interaction on Agricultural and Quality in Sainfoin (Onobrychis sativa) Genotypes. Journal of Animal and Veterinary Advances, 12, 428 - 430.

Ball, D.M., Collins, M., Lacefield, G.D., Martin, N.P., Mertens, D.A, Olson, K.E., Putnam, D.H., Undersander, D.J., Wolf, M.W. (2001). Understanding forage quality. American Farm Bureau Federation Publication 1-01, Park Ridge, IL.

Barry, T.N. (1987). Secondary compounds of forages. In "Nutrition of herbivores", Ed; Hacker, JB and Ternouth JH, Academic Press, pp. 91-119. Sydney, Australia.

Baydar, H. (2000). Bitkilerde Yağ Sentezi, Kalitesi ve Kaliteyi Artırmada Islahın Önemi. Ekin Dergisi, 11, 50-57.

Bozkurt, K.A. (2011). Determination of relative feed value of some legume hays harvested at flowering stage. Asian Journal of Animal and Veterinary Advances. 6, 525-530.

Canbolat, O., Karaman, S. (2009). Comparison of in Vitro Gas Production, Organic Matter Digestibility, Relative Feed Value and Metabolizable Energy Contents of Some Legume Forages. Tarrm Bilimleri Dergisi. 15, 188-195.

Dumlu, S. E., Çakal, Ş., Aksakal, E., Mustafa, Uzun., Özgöz, M.M., Terzioğlu, K., Uyusal., P. Atıcı., M. Menteşe, Ö. (2017). Determination of The Performance of Alfalfa Variety Candidate in The Ecological Conditions of Erzurum. Alınteri Zirai Bilimler Dergisi, 32(2), 55-61.

Elçi, Ş. (2005). Legume and grass forage crops (Baklagil ve buğdaygil yem bitkileri), T.C. Tarım ve Köyişleri Bakanlığı, s. 223-257, Ankara. 


\section{Current Trends in Natural Sciences}

Vol. 9, Issue 17, pp. 83-88, 2020

https://doi.org/10.47068/ctns.2020.v9i17.009

Current Trends in Natural Sciences (on-line)

ISSN: 2284-953X

Current Trends in Natural Sciences (CD-Rom)

ISSN: 2284-9521

ISSN-L: 2284-9521

ISSN-L: 2284-9521

Engin, B., Mut, H. (2017). Determination of Hay Yield and Some Quality Traits of Different Alfalfa Cultivars. $Y Y U J$ Agr Sci, 27(2), 212-219.

Genctan, T., (1998). Agricultural Ecology (Tarımsal Ekoloji), Trakya Üniversitesi Tekirdağ Ziraat Fakültesi, Tarla Bitkileri Bölümü, Tekirdağ, 191s.

Kumar, R., Singh, M. (1984). Tannins: their adverse role in ruminant nutrition. Agric Food Chem, 32(3), $447-453$.

Makkar, H.P.S., Blummel, M., Becker, K. (1995). Formation of complexes between polyvinyl pyrrolidones or polyethylene glycols and their implication in gas production and true digestibility in vitro techniques. Brit $J$ Nutr, 73(6), 897-913.

Parlak, A.Ö., GökkuĢ, A., Samıkıran E., Senol M.Y., 2014. Investigation of Morphological and Agronomic Characteristics of Some Wild Sainfoin Species. COMU Journal of Agriculture Faculty, 2 (2), 111-117.

SAS 1999. SAS User's Guide: Statistic. Statistical Analysis Systems Institute Inc., Cary, NC.

Ülger, I., Kaplan, M. (2016). Variations in Potential Nutritive Value, Gas and Methane Production of Local Sainfoin (Onobrychis sativa) Populations. Alınteri Zirai Bilimler Dergisi, 31(2), 42-47.

Van Soest, P. J., Wine, R.H. (1967) The use of detergents in the analysis of fibrous feeds. IV. Determination of plant cell wall constituents. JAOAC, 50, 50-55.

Van Soest, P.J. (1994). Nutritional ecology of the ruminant (2nd Ed.). pp. 528. Cornell University Press. Ithaca, NY, 1994.

Van Soest, P.J. (1963). The use of detergents in the analysis of fibrous feeds. II. A rapid method for the determination of fiber and lignin. JAOAC, 46, 829-835.

Yolcu, H., Tan, M. (2008). General View to Turkey Forage Crops Cultivation. Tartm Bilimleri Dergisi, 14(3), 303-312. 